\title{
Increased folivory in brown spider monkeys Ateles hybridus living in a fragmented forest in Colombia
}

\author{
Ana Gabriela de Luna ${ }^{1,2}$, Andrés Link ${ }^{2,3, *}$, Andrés Montes ${ }^{2,4}$, Felipe Alfonso ${ }^{2,5}$, \\ Leonardo Mendieta ${ }^{2,6}$, Anthony Di Fiore ${ }^{2,7}$
}

\author{
${ }^{1}$ Departamento de Biología y Antropología Física, Universidad Complutense de Madrid, Calle Jose Antonio Novais No. 2 , \\ Ciudad Universitaria, Madrid 28040, Spain \\ ${ }^{2}$ Fundación Proyecto Primates, Cra. 11A No. 91-55 Bogota, Colombia \\ ${ }^{3}$ Departamento de Ciencias Biológicas y Facultad de Administración, Universidad de Los Andes, Cra. 1 No. 18A-12 Bogota, \\ Colombia \\ ${ }^{4}$ Departamento de Biología, Universidad del Tolima, Barrio Santa Helena Parte Alta 730006299 Ibague, Tolima, Colombia \\ ${ }^{5}$ Departamento de Biología, Pontificia Universidad Javeriana, Carrera 7 No. 40-62 Bogota, Colombia \\ ${ }^{6}$ Departamento de Biología, Universidad de Caldas, Calle 65 No. 26-10 Manizales, Colombia \\ ${ }^{7}$ Department of Anthropology, University of Texas at Austin, University of Texas, Austin, TX 78712, USA
}

\begin{abstract}
Brown spider monkeys Ateles hybridus are one of the most threatened primates in the Neotropics. Most of the remaining populations of this species already live either in forest fragments or in areas that face imminent anthropogenic disturbance. Understanding how these animals cope with the challenge of living in small fragments, while at the same time being a large, frugivorous mammal is crucial to design effective conservation and management strategies. We studied the diet of wild A. hybridus and measured forest productivity in a small ( 65 ha) fragment in the Magdalena Region of northern Colombia over a period of 26 mo. Spider monkeys at this site spent far less time feeding on fruits than reported in previous studies of Ateles spp. living in less fragmented sites. Moreover, we registered a high consumption of leaves in every month (on average $37 \%$ of their feeding time) as well as the consistent inclusion of decayed wood in the diet. Ficus trees can be considered staple feeding items, as they were present in high proportions in the monkeys' diet throughout the study. Although wild populations of spider monkeys can have flexible diets that include large proportions of leaves over long periods of time, they may also be exposed to a suboptimal diet which may have negative implications for their reproduction and well-being in the long run, further compromising the viability of wild populations living in disturbed habitats.
\end{abstract}

KEY WORDS: Behavioral flexibility $\cdot$ Ficus $\cdot$ Habitat fragmentation $\cdot$ Leaf consumption

\section{INTRODUCTION}

Habitat loss and fragmentation are globally pervasive processes that have increased in recent decades in the remaining tropical forests of the world (Achard et al. 2002, Fahrig 2003). For example, in Latin America and the Caribbean, Aide et al. (2013) estimated that between 2001 and 2010 deforestation resulted in the conversion of $>540000 \mathrm{~km}^{2}$ of tropical woody

\footnotetext{
*Corresponding author: a.link74@uniandes.edu.co
}

vegetation into agricultural fields and pastures. Although other large areas also began natural recovery processes during this time (Aide et al. 2013), it may be decades before these areas attain the structure, composition and functionality of the original habitats and ecosystems.

For New World primates, fragmentation poses a major threat to wild populations, given their almost strictly arboreal habits (Rosenberger \& Strier 1989).

(C) The authors 2017. Open Access under Creative Commons by Attribution Licence. Use, distribution and reproduction are unrestricted. Authors and original publication must be credited. 
Habitat degradation and fragmentation have direct effects on the viability of primate populations via the reduction of potential habitat (Link et al. 2010, Arroyo-Rodríguez et al. 2013, Chapman et al. 2013) and the limitation of gene flow between isolated populations (Templeton et al. 1990, Ganzhorn et al. 2015, Mbora \& McPeek 2015). At the same time, habitat degradation and fragmentation also influence the behavior and ecology of primates (see Marsh et al. 2013 and references therein). Amongst Neotropical rainforest vertebrates, spider monkeys (genus Ateles) are one of the most threatened taxa (IUCN 2015) and one of the first to go locally extinct in fragmented landscapes (Michalski \& Peres 2005). Their long reproductive cycles (females begin reproducing at the age of 7 to $9 \mathrm{yr}$ and have a single offspring every $3 \mathrm{yr}$ ) make them vulnerable to drivers of population decline such as habitat loss (Link et al. 2013), hunting (Franzen 2006) and disease (Holzmann et al. 2010). Also, given their large body size (ca. 8 to $10 \mathrm{~kg}$ ) and reliance on ripe fleshy fruits in their diets, spider monkeys generally require large territories in order to fulfill their energetic needs (Di Fiore et al. 2008). Nonetheless, spider monkeys are able to cope with seasonal variation in fruit availability by adjusting foraging subgroup size (thereby reducing direct competition for feeding resources) and/or by adjusting their diets to include a larger proportion of other complementary and more readily available items, such as young leaves (Di Fiore et al. 2008).

Species with flexible grouping patterns such as spider monkeys and chimpanzees (Symington 1990) can balance the costs and benefits of group living by adjusting their foraging subgroup size to the immediate social and ecological conditions (Lehmann \& Boesch 2004, Aureli et al. 2008). Spider monkeys show a high degree of fission-fusion dynamics, in which stable social groups (15 to 55 ind.) frequently break apart into smaller subgroups that vary in size and composition (Symington 1990). Given their frugivorous diet and large body size, fission-fusion association patterns in spider monkeys might allow individuals to reduce intra-group feeding competition by ranging in smaller subgroups during periods of fruit scarcity (Steenbeek et al. 1999, Shimooka 2003, Asensio et al. 2008, 2009). For example, at Tinigua Park, Colombia, spider monkeys ranged, on average, in larger subgroups during the period of fruit abundance than during the period of fruit scarcity, while individuals were more often solitary during low fruit periods (Shimooka 2003).

An alternative and non-exclusive strategy used by spider monkeys for coping with periods of fruit scarcity is increasing the intake of leaves and other supplementary feeding items during periods of fruit shortage (Castellanos \& Chanin 1996, Felton et al. 2008). Spider monkeys are considered ripe fruit 'specialists' because in most studies across their geographical distribution they feed on a wide variety of ripe, fleshy fruits, which generally constitute 75 to $90 \%$ of their yearly diet (Di Fiore et al. 2008, González-Zamora et al. 2009). Several studies on spider monkeys have found a positive relationship between habitat-wide fruit availability and fruit consumption (Klein \& Klein 1977, Symington 1987, Chapman 1990, Chapman et al. 1995, Stevenson et al. 2000). Nonetheless, spider monkeys that live in areas with contrasting rainfall seasons and marked differences in fruit availability throughout the year can temporarily adjust their diet to rely more heavily on young leaves and other items (Chapman 1987, Symington 1987, Castellanos \& Chanin 1996, Stevenson et al. 2000, González-Zamora et al. 2009, Chaves et al. 2011). Finally, spider monkeys complement their frugivorous diet with leaves, flowers, unripe fruit, other plant parts, decayed wood (Klein \& Klein 1977, Suarez 2006, Di Fiore et al. 2008), clay from mineral licks (Izawa 1993, Link et al. 2011b) and occasionally, insects (Link 2003).

Habitat fragmentation may have direct and indirect effects on habitat-wide productivity and on the availability of ripe fleshy fruits as smaller fragments are generally associated with modified vegetation structure and composition (Hill \& Curran 2003). Small fragments are often lacking in large fruiting trees and have less diverse tree communities, thus reducing their overall fruit productivity and potentially increasing the durations of fruit scarcity periods (Arroyo-Rodríguez \& Mandujano 2006). Under these conditions, spider monkeys must rely on more readily available items (e.g. leaves), or on keystone plant species (e.g. Ficus spp.) during periods of habitatwide fruit scarcity (Felton et al. 2008).

To date, most studies on the feeding ecology of spider monkeys have been conducted in forests with little or no human intervention. However, recent studies aiming to compare the diets of spider monkeys in both fragmented and continuous areas have documented that, in a similar way to the dietary response to periods of fruit scarcity, spider monkeys tend to include a larger proportion of leaves in their diet when they are constrained into small forest fragments (González-Zamora et al. 2009). Nonetheless, there is still little information on how they may cope with habitat fragmentation and its long-term implications on the persistence of their wild populations. 
Brown spider monkeys Ateles hybridus are one of the most endangered primates in the Neotropics (Mittermeier et al. 2009), and only a single previous study has focused on describing their feeding behavior (Link et al. 2012). At Serranía de Las Quinchas, an inter-Andean forest site in northern Colombia, brown spider monkeys fed almost exclusively on ripe, fleshy fruits all year (Link et al. 2012) and only complemented their diet with leaves and other items for approximately $6 \%$ of the time they spent feeding. Spider monkeys at Las Quinchas frequently visit mineral licks, in a similar pattern to the behavior of spider monkeys in western Amazonia (Izawa 1993, Link et al. 2011a,b), to obtain complementary nutrients or minerals not readily available in their diets or to mitigate the effects of secondary metabolites contained in leaves and other vegetative parts of plants (Krishnamani \& Mahaney 2000).

Here, we describe the diet of 2 groups of brown spider monkeys living in a small forest fragment in the inter-Andean Rio Magdalena valley in northern Colombia. We provide evidence on how Critically Endangered brown spider monkeys are able to cope with the challenges of forest fragmentation and living at high population densities (see Link et al. 2010 for details), and we assess the importance of the availability of fleshy fruits on their dietary composition. This study builds on the existing broad literature on the diets of spider monkeys by documenting the diet of a population of brown spider monkeys living in a heavily fragmented area where the monkeys have also been the subject of long-term, longitudinal study.

\section{MATERIALS AND METHODS}

\section{Study area}

The study site consisted of a small fragment of approximately 65 ha of seasonally flooded, lowland forest (90 m a.s.1.) along the San Juan River, within the floodplains of the Magdalena River in the province of Santander, Colombia $\left(6^{\circ} 42^{\prime} 58.2^{\prime \prime} \mathrm{N}, 74^{\circ} 08^{\prime}\right.$ $\left.02.7^{\prime \prime} \mathrm{W}\right)$. The site was located within Hacienda San Juan del Carare (hereafter San Juan), a private cattle ranch made up of a mosaic of pastures, wetlands and small patches of forest, with an average annual rainfall of $3458 \mathrm{~mm}$. This area has an annual bimodal rainfall cycle, with rainy seasons between March and May and between September and November, and drier seasons between December and February and between June and August. During peak rainy periods, the entire study site floods for periods that range between a few days to several weeks. The study fragment is covered by $\sim 9 \mathrm{~km}$ of mapped and georeferenced trails, and contains over 2000 marked and mapped trees in which spider monkeys were recorded feeding throughout the study.

\section{Study subjects and field methods}

This study was conducted on 2 neighboring groups of brown spider monkeys living in the study fragment. Most of the data was collected on a single study group, SJ-1, which over the course of the study contained 2 to 4 adult males and 5 to 6 adult females and their dependent offspring. The second study group comprised a single adult male and 5 adult females and their dependent offspring at the time of the study.

We conducted dawn-to-dusk behavioral follows and collected systematic data on the feeding behavior of animals from the 2 study groups for approximately 3 yr, from July 2009 through March 2012. Data collection was not continuous throughout the study period, given the intense rainy seasons of 2010 and 2011 which prevented us from collecting data during certain months when flooding made portions of the study fragment inaccessible. We used focal animal sampling (Altmann 1974), attempting to follow a single focal animal for the entire day and balancing focal animal follows in order to have similar sampling for all adults and subadults in the 2 groups.

During behavioral follows, we collected instantaneous point samples of the behavior of our focal subject at 5-min intervals, based on a comprehensive behavioral protocol and ethogram developed during our long-term research on spider monkeys in Colombia and Ecuador (A. Di Fiore \& A. Link unpubl. data). Data on the activity patterns of spider monkeys were extracted from these 5-min point samples, in which we recorded 1 out of 5 general activities for the focal individual: (1) feeding, (2) moving, (3) resting, (4) social activities and (5) other non-social activities.

In order to quantify the diet of brown spider monkeys at San Juan, we documented continuous records of all feeding events from our focal animal by recording the start and end time of each feeding bout (thus, its duration), the species or morphospecies consumed, and the item eaten (e.g. fruits, young leaves, etc.). In addition, for all major feeding sources (i.e. those used by the focal animal for $>5 \mathrm{~min}$ ) we tagged the tree with a unique ID number, and we recorded its diameter at breast height $(\mathrm{DBH})$ and spatial location. Locations were recorded by measuring the distance and angle of the tree from one of the 
roughly 2500 reference points within the study fragment that had been previously mapped and georeferenced using a handheld GPS with a high sensitivity antenna. We collected botanical vouchers for all trees and lianas included in the diet of brown spider monkeys, and identified them either at the Herbarium at Universidad de Los Andes Natural History Museum or at the Dendrology Laboratory at Universidad del Tolima.

\section{Forest productivity}

We estimated habitat-wide fruit availability within the study fragment by conducting regular phenological surveys and estimating the productivity of ripe fleshy fruits (the main feeding item in spider monkey diets; Di Fiore et al. 2008), following the methods developed by Stevenson (2002). Every $2 \mathrm{wk}$, we sampled 8 transects covering roughly 6500 linear meters and recorded phenological information for all trees and lianas whose crowns fell within $1 \mathrm{~m}$ of the transect line and that were bearing ripe fruits during the particular monitoring cycle. Transects were walked slowly, and fruiting trees and lianas were detected directly by examining the overlying crown or by indirect cues of fruits and flowers in the forest floor. For each fruiting tree, we recorded its $\mathrm{DBH}$, perpendicular distance to the transect, and spatial location along the transect. Each tree was also tagged with a unique ID number. In order to estimate the effective sampling area covered in our surveys, we averaged the perpendicular distance of all fruiting trees from the transect and used this average distance as half the transect width (as it is considered at both sides of the transect), which, multiplied by the total distance covered for each phenological sampling, gave us the total estimated sampling area (see Stevenson 2002 for details).

This research project was conducted under the institutional guidelines from Universidad de Los Andes and the approval of Ministerio de Medio Ambiente y Desarrollo Sostenible, and complied with the ethical standards for the study of endangered primates in their natural habitats.

\section{Data analyses}

We quantified the time spent feeding by spider monkeys throughout the study as the proportion of 5min point samples in which we recorded the focal animal feeding, divided by the total number of point samples in the study. Then, based on the continuous feeding records from our focal animal samples, we calculated the proportion of time brown spider monkeys spent feeding on the different food items and on the different species of trees and lianas throughout the study. We partitioned these data by months in order to evaluate variability in the monkeys' feeding strategies across the study period, and to evaluate the effect of fruit availability on their diet. We compared the diets of the 2 study groups, and that of males versus females, using Mann-Whitney $U$-tests.

We employed the 'preference index' proposed by Krebs (1989) and used by Felton et al. (2008) in order to evaluate which trees and lianas were preferred by brown spider monkeys. The index is calculated as:

$$
E_{i}=\left(r_{i}-n_{i}\right) /\left(r_{i}+n_{i}\right)
$$

where $r_{i}$ is the percentage of species $i$ in the diet, and $n_{i}$ is the relative abundance of species $i$ in the area, which we calculated as the basal area of species $i$ per ha (Krebs 1989). Preference index values can range between -1 (for avoided trees or lianas) and +1 (for highly preferred trees or lianas). Data on forest structure and diversity were taken from botanical work done at San Juan (Villanueva 2008).

In order to estimate biweekly habitat-wide productivity, we used 2 variables as proxies of fruit availability within the study fragment: (1) the number of fruiting trees and lianas in phenological transects during each period, and (2) the basal area of all fruiting trees and lianas in the transect. Given that the fruiting periods of most tropical trees and lianas may fall in 2 or more biweekly periods, we divided the contribution of each fruiting tree along its fruiting period by assigning a coefficient derived from Pascal triangles (see Stevenson 2002) to each fruiting period and then multiplying this coefficient by its basal area. Thus, a tree fruiting for 3 consecutive periods would have its basal area (as an index of its productivity) assigned $0.25,0.50$ and 0.25 to each of the 3 fruiting periods, respectively. Finally, we used a Spearman's correlation test in order to evaluate the relationship between fruit availability and the proportion of fruits in the diet of brown spider monkeys.

\section{RESULTS}

Overall, we completed $2052 \mathrm{~h}$ of focal animal sampling on our 2 study groups (SJ-1: 1890 h; SJ-2: $162 \mathrm{~h})$. Spider monkeys spent most of their time resting (mean \pm SD: $45.2 \pm 6.2 \%, \mathrm{n}=20$ ind.), and invested almost a quarter of their time feeding $(25.9 \pm$ 


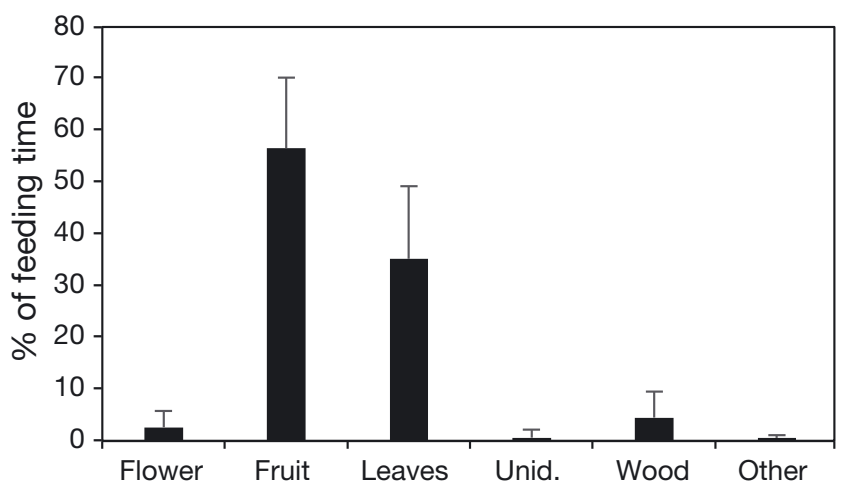

Fig. 1. Diet of brown spider monkeys Ateles hybridus in a fragmented forest in San Juan de Carare, Colombia. Bars represent the percentage of feeding time for different items. Error bars show SD. Unid: unidentified

$2.8 \%)$ and moving $(23.8 \pm 3.5 \%)$, while devoting only a small proportion of their time to social behavior $(4.4$ $\pm 4.0 \%)$ and other non-social activities $(0.6 \pm 0.6 \%)$. We recorded 4818 feeding bouts in which brown spider monkeys invested a total of $29651 \mathrm{~min}(494.2 \mathrm{~h})$ feeding, which accounted for $24 \%$ of the total sampling time. The average proportion of time spent feeding by the 14 adult individuals in our main study group was $24.8 \pm 3.7 \%$ (range: 17.9 to $30.7 \%$ ) based on the 5-min point samples.

At San Juan de Carare, the diet of brown spider monkeys included items such as ripe fruits, young leaves, flowers, decayed wood, soil from termite nests and water, amongst others. Although ripe fruits were the most intensively used item, the monkeys spent only $54.1 \%$ of their feeding time eating ripe fruits. Consumption of young leaves accounted for $37.2 \%$ of their feeding time, while eating flowers from a few species $(n=8)$ and decayed wood comprised 3.9 and $3.2 \%$ of their feeding time, respectively. Only $1.6 \%$ of their feeding time was spent on items that were not identified (Fig. 1).

\section{Temporal variation in diet of brown spider monkeys}

Even though behavioral follows had to be interrupted during several months due to floods in the study area, we were able to record the diet of brown spider monkeys at San Juan for a total of 26 mo over a period of $3 \mathrm{yr}$. Although the temporal variation in the diet of brown spider monkeys at San Juan was not as marked as that of other populations of wild spider monkeys (Chapman et al. 1995, Di Fiore et al. 2008), the consumption of fruits reached monthly levels comparable to that of other Ateles populations (up to $74 \%$ of the monthly diet). Nonetheless, the proportion of fruits consumed in some months was sometimes quite low, accounting for as little as $34 \%$ of their feeding time (Fig. 2). Brown spider monkeys at San Juan ate decayed wood from dead-standing trees during almost all months of the study. Decayed

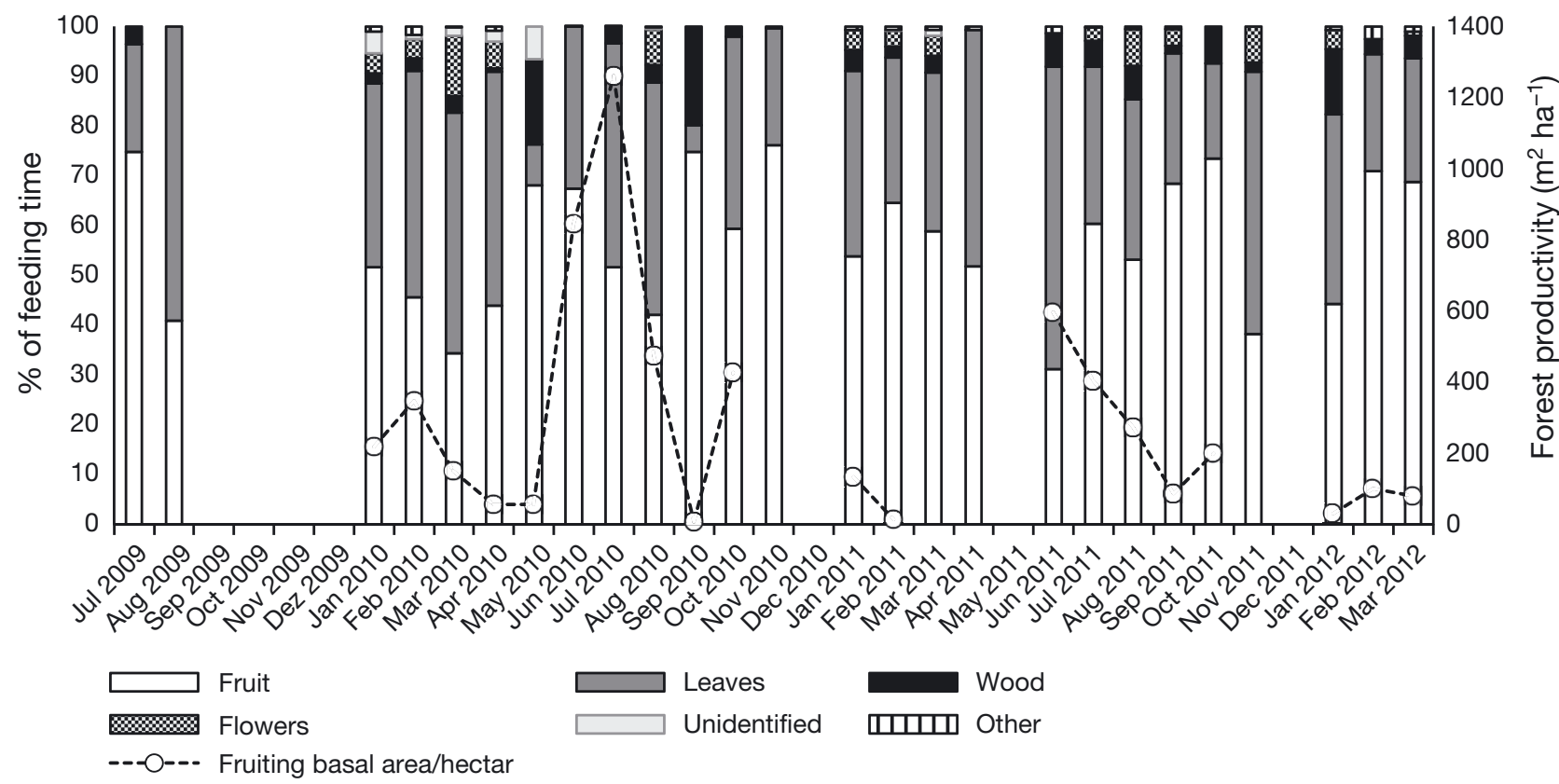

Fig. 2. Monthly proportions of items included in the diet of brown spider monkeys Ateles hybridus (bars) and estimates of habitat-wide fruit availability (dashed line) at San Juan de Carare, Colombia 
wood represented $3.1 \%$ of their overall diet, although in some months it accounted for as much as $12 \%$ of their feeding time (Fig. 2). Flowers were also part of brown spider monkeys' diet in 23 of the 26 mo sampled.

\section{Group, sex and individual variation in diet}

Although sampling effort was not evenly divided between study groups, we did not find any differences in the time individuals from each study group spent feeding on different items (flowers: MannWhitney $U=183, \mathrm{p}=0.67$; fruits: Mann-Whitney $U=$ 3104, $\mathrm{p}=0.35$; leaves: Mann-Whitney $U=3121, \mathrm{p}=$ 0.46; wood: Mann-Whitney $U=236, \mathrm{p}=0.92$ ). Also, we did not find differences between the sexes in the proportion of time spent feeding on any particular item (flowers: Mann-Whitney $U=414, \mathrm{p}=0.19$; fruits: Mann-Whitney $U=9494, \mathrm{p}=0.58$; leaves: MannWhitney $U=9573, \mathrm{p}=0.44$; wood: Mann-Whitney $U$ $=610, p=0.58)$. In both study groups, ripe fruits were the most common item included in the diet (54\% for group SJ-1; 59 \% for group SJ-2). Leaves also composed a major feeding item in both study groups, accounting for 38 and $32 \%$ of the feeding time of SJ-1 and SJ-2, respectively.

\section{Dietary diversity}

The diet of brown spider monkeys at San Juan included at least 55 plant species from 47 different genera and 24 plant families (Table 1). We were unable to identify the plant species consumed for a large percentage of feeding events, corresponding to $23 \%$ of feeding time; these were mainly from short feeding bouts (<1 $\mathrm{min})$ where the animals fed on young leaves from canopy lianas. The most important family in the diet was Moraceae, comprising $34.4 \%$ of the monkeys' total feeding time and including at least 3 of the most important species in their diet (see below). Other key families in the diet of brown spider monkeys at San Juan included Malvaceae $(11.7 \%)$, Fabaceae $(4.7 \%)$, Polygonaceae $(4.1 \%)$, and Annonaceae (4.1\%). Of the 27 plant families included in the diet, only 12 individually accounted for $>1 \%$ of the total feeding time (Table 1 ).

In a similar pattern to that described in other studies on spider monkeys, only a handful of species individually constituted a large proportion of their diet. The 5 most intensively consumed species accounted for almost half of the diet (46\%). Three figs
(Ficus dendrocida, F. insipida, and Ficus sp. [not identified to species level]) were amongst the most consumed species, contributing to $11.9,11.8$ and $7.5 \%$ of the total feeding time, respectively. Other important species included Guazuma ulmifolia (10.2\% of feeding time) and Coccoloba lehmannii (4.1\%) (Fig. 3).

Brown spider monkeys fed on fig trees during all 26 mo of the study, and consumption of various parts of fig trees accounted for $31.8 \%$ of their time spent feeding. During $17 \mathrm{mo}$, figs accounted for at least $25 \%$ of the monthly diet (Fig. 4), and in 4 mo, figs comprised more than half of their feeding time. Interestingly, the monkeys fed not only on ripe and unripe Ficus fruits, but also included a high percentage of leaves during their time feeding on fig trees.

\section{Habitat-wide fruit availability}

During the study period, we recorded a total of 2913 individual trees and lianas from 60 different species that produced ripe fleshy fruits. Given that the average distance of all fruiting trees to the center of the phenological transect was $4.4 \mathrm{~m}$, we estimated our sampling area as $28380 \mathrm{~m}^{2}$ (2.84 ha). The average fruiting tree density per monitoring period was 30.9 trees $\mathrm{ha}^{-1}$, and the average total basal area of trees bearing fruits in each monitoring period was $8576330 \mathrm{~cm}^{2}$ (Table 2). Across 36 monitoring periods, these 2 variables, used to estimate habitat-wide productivity, were highly correlated (Spearman's $\mathrm{r}=$ 0.499, $\mathrm{p}=0.002$ ).

Finally, we did not find a significant relationship between ripe fruit availability and the proportion of ripe fruits included in the brown spider monkeys' diet. When we used the number of fruiting trees per monitoring period as a proxy of fruit availability, we found that there was no relationship between productivity and fruit consumption $(\mathrm{r}=0.071 \mathrm{p}=0.77$, $\mathrm{n}=20$ ) (Fig. 2). When we used the basal area of fruiting trees as a proxy of habitat-wide fruit availability, contrary to our expectations, we found a negative but non-significant relationship between fruit availability and the proportion of the diet made up of ripe fruits (Spearman's $r=-0.403, p=0.08, n=20$ ) (Fig. 2).

\section{DISCUSSION}

Brown spider monkeys living in the seasonally flooded forest of San Juan have one of the most folivorous and least diverse diets reported for Ateles. 
Table 1. Species consumed by brown spider monkeys Ateles hybridus in the studied forest fragment in San Juan de Carare, For a description of the preference index see 'Materials and methods: Data analyses'. Columbia. FR: fruits; FL: flowers; L: leaves; DW: decayed wood; OT: other

\begin{tabular}{|c|c|c|c|c|}
\hline Family & Species & Item & $\begin{array}{l}\text { Feeding time } \\
\text { (min) }\end{array}$ & $\begin{array}{l}\text { Preference } \\
\text { index }\end{array}$ \\
\hline Anacardiaceae & Spondias mombin L. & FR & 745 & -0.58 \\
\hline Annonaceae & Duguetia colombiana Maas & $\mathrm{FR}, \mathrm{L}$ & 123 & -0.12 \\
\hline Annonaceae & Oxandra sp. & FR & 9 & -0.72 \\
\hline Annonaceae & Pseudomalmea boyacana (J.F.Macbr.) Chatrou & FL, FR, L & 695 & 0.71 \\
\hline Annonaceae & Xylopia amazonica R.E. Fr. & FR & 371 & 0.61 \\
\hline Araceae & Anthurium sp. & $\mathrm{L}$ & 20 & \\
\hline Araceae & Syngonium sp. & $\mathrm{L}$ & 107 & \\
\hline Arecaceae & Bactris pilosa H. Karst. & FR & 18 & \\
\hline Bixaceae & Cochlospermum orinocense (Kunth) Steud. & $\mathrm{L}$ & 90 & \\
\hline Boraginaceae & Cordia collococca L. & FR & 632 & 0.16 \\
\hline Chrysobalanaceae & Hirtella bicornis Mart. \& Zucc. & FR & 44 & \\
\hline Chrysobalanaceae & Licania platypus (Hemsl.) Fritsch & FR & 68 & -0.87 \\
\hline Clusiaceae & Garcinia madruno (Kunth) Hammel & FR & 7 & \\
\hline Clusiaceae & Garcinia sp. & FR & 9 & \\
\hline Convolvulaceae & Maripa panamensis Hemsl. & FL, FR, L & 218 & \\
\hline Fabaceae & Cassia grandis L. f. & FL, FR, L & 701 & 0.45 \\
\hline Fabaceae & Erythrina glauca Willd. & FL, L & 44 & \\
\hline Fabaceae & Inga pezizifera Benth. & FR, L & 297 & 0.90 \\
\hline Fabaceae & Inga punctata Willd. & $\mathrm{FR}, \mathrm{L}$ & 3 & -0.79 \\
\hline Fabaceae & Machaerium capote Triana ex Dugand & $\mathrm{FR}, \mathrm{L}$ & 165 & \\
\hline Fabaceae & Ormosia colombiana Rudd & $\mathrm{L}$ & 4 & -0.95 \\
\hline Fabaceae & Senegalia polyphylla (DC.) Britton \& Rose & $\mathrm{L}$ & 41 & -0.73 \\
\hline Fabaceae & Zygia longifolia (Humb. \& Bonpl. ex Willd.) Britton \& Rose & $\mathrm{L}$ & 27 & -0.93 \\
\hline Gnetaceae & Gnetum leyboldii Tul. & FR & 498 & \\
\hline Lecythidaceae & Gustavia dubia (Kunth) O. Berg & FR & 66 & 0.06 \\
\hline Loganiaceae & Strychnos panamensis Seem. & FR & 60 & \\
\hline Loganiaceae & Strychnos sp. & FR & 62 & \\
\hline Malvaceae & Guazuma ulmifolia Lam. & FR, L & 3007 & 0.69 \\
\hline Malvaceae & Luehea seemannii Triana \& Planch. & $\mathrm{L}$ & 8 & \\
\hline Malvaceae & Pseudobombax septenatum (Jacq.) Dugand & $\mathrm{L}$ & 67 & 0.85 \\
\hline Malvaceae & Vasivaea podocarpa Kuhlm. & FR, L & 374 & 0.80 \\
\hline Meliaceae & Trichilia pallida Sw. & FR & 340 & 0.63 \\
\hline Menispermaceae & Chondodendron tomentosum Ruiz \& Pav. & FR & 14 & \\
\hline Moraceae & Clarisia biflora Ruiz \& Pav. & FL, FR, L & 619 & 0.59 \\
\hline Moraceae & Ficus amazonica (Miq.) Miq. & FR, L & 109 & \\
\hline Moraceae & Ficus crassiuscula Warb. ex Standl. & $\mathrm{FR}, \mathrm{L}$ & 39 & \\
\hline Moraceae & Ficus dendrocida Kunth & FR, L, DW & 3504 & \\
\hline Moraceae & Ficus hoja lanceolada & $\mathrm{L}$ & 28 & \\
\hline Moraceae & Ficus insipida Willd. & FL, FR, L, DW, OT & 3482 & -0.06 \\
\hline Moraceae & Ficus sp. & FL, FR, L, DW, OT & 2210 & \\
\hline Moraceae & Maclura tinctoria (L.) D. Don ex Steud. & $\mathrm{FR}, \mathrm{L}$ & 125 & \\
\hline Moraceae & Sorocea pubivena Hemsl. & FL & 38 & \\
\hline Myrtaceae & Eugenia biflora (L.) DC. & FR, L & 718 & 0.95 \\
\hline Polygonaceae & Coccoloba lehmannii Lindau & FR, L & 1217 & 0.81 \\
\hline Rubiaceae & Faramea capillipes Müll. Arg. & FR & 4 & -0.92 \\
\hline Rubiaceae & Genipa americana L. & FR & 176 & -0.42 \\
\hline Salicaceae & Laetia corymbulosa Spruce ex Benth. & FR & 9 & 0.11 \\
\hline Salicaceae & Tetrathylacium johanseni Standl. & FR & 197 & 0.64 \\
\hline Sapindaceae & Dilodendron costaricense (Radlk.) A.H. Gentry \& Steyerm. & FR & 108 & -0.02 \\
\hline Sapindaceae & Paullinia bracteosa Radlk. & FR & 1 & \\
\hline Sapindaceae & Talisia cerasina (Benth.) Radlk. & FR & 14 & \\
\hline Sapotaceae & Chrysophyllum sp. & FR & 169 & \\
\hline Sapotaceae & Pouteria baehniana Monach. & $\mathrm{FR}$ & 542 & 0.56 \\
\hline Sapotaceae & Sarcaulus brasiliensis (A. DC.) Eyma & FR & 40 & \\
\hline Urticaceae & Cecropia membranacea Trécul & FR, L & 230 & 0.88 \\
\hline Other & & & 195 & \\
\hline Unidentified & & & 6943 & \\
\hline
\end{tabular}



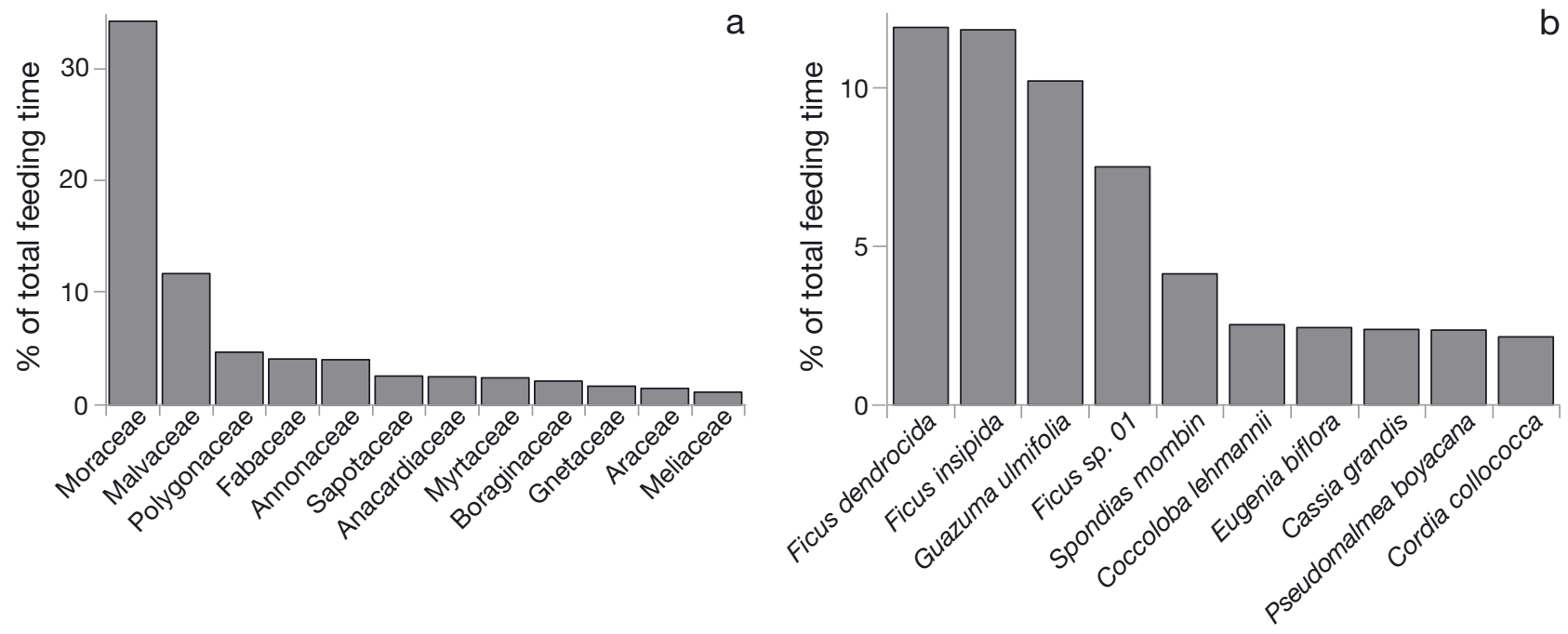

Fig. 3. Most common (a) families and (b) species in the diet of brown spider monkeys Ateles hybridus at San Juan de Carare, Colombia

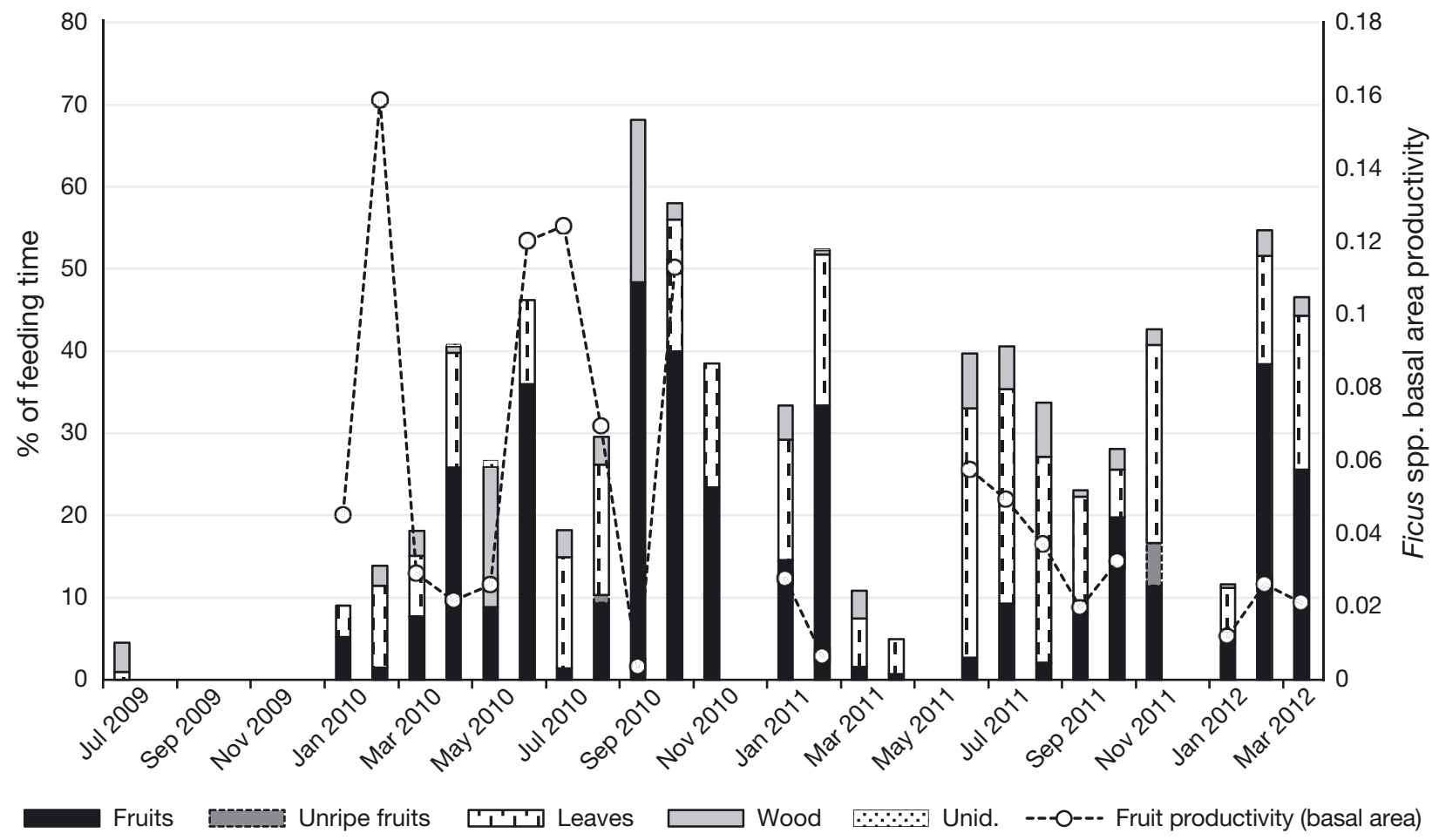

Fig. 4. Feeding time invested by brown spider monkeys Ateles hybridus in eating different parts of Ficus spp. trees, and Ficus spp. productivity. Unid.: unidentified

Contrary to an earlier study on the diet of A. hybridus in another inter-Andean forest at Serranía de Las Quinchas approximately $75 \mathrm{~km}$ away (Link et al. 2012), brown spider monkeys at San Juan relied heavily on young leaves year-round, and in fact, leaves comprised approximately $37 \%$ of their annual diet, with as much as $74 \%$ of the animals' time spent feeding on leaves in some months. Also, contrary to results found by Chaves et al. (2012) on the dietary differences between Central American spider monkeys in which spider monkeys living in smaller fragments tended to diversify their overall diet, the diet of brown spider monkeys at San Juan was less diverse than that of populations living in the less disturbed 
Table 2. Monthly forest productivity. Period I: Days 1 to 15 of each month; Period II: Days 16 to the end of the month. Distance: length of the phenological transect each month. Given that some parts of the forest flood, distances can vary across months

\begin{tabular}{|c|c|c|c|c|c|c|}
\hline Date & Period & $\begin{array}{l}\text { Distance } \\
(\mathrm{m})\end{array}$ & $\begin{array}{c}\text { No. } \\
\text { of } \\
\text { trees }\end{array}$ & $\begin{array}{c}\text { Sampled } \\
\text { area } \\
\text { (ha) }\end{array}$ & $\begin{array}{c}\text { Density } \\
\text { (trees } \\
\mathrm{ha}^{-1} \text { ) }\end{array}$ & $\begin{array}{l}\text { Basal area } \\
\qquad\left(\mathrm{cm}^{2}\right)\end{array}$ \\
\hline Dec-09 & I & 6457 & 85 & 2.84 & 29.92 & 451184.32 \\
\hline \multirow[t]{2}{*}{ Jan-10 } & I & 6307 & 91 & 2.77 & 32.79 & 249290.63 \\
\hline & II & 6457 & 47 & 2.84 & 16.54 & 190145.32 \\
\hline \multirow[t]{2}{*}{ Feb-10 } & I & 6307 & 48 & 2.77 & 17.29 & 1532602.58 \\
\hline & II & 3500 & 7 & 1.54 & 4.54 & 13710.52 \\
\hline \multirow[t]{2}{*}{ Mar-10 } & I & 6117 & 73 & 2.69 & 27.12 & 183667.60 \\
\hline & II & 5642 & 62 & 2.48 & 24.97 & 98982.08 \\
\hline \multirow[t]{2}{*}{ Apr-10 } & I & 6277 & 54 & 2.76 & 19.55 & 145694.80 \\
\hline & II & 6267 & 63 & 2.75 & 22.84 & 64935.50 \\
\hline May-10 & I & 6307 & 36 & 2.77 & 12.97 & 125892.64 \\
\hline Jun-10 & I & 6457 & 104 & 2.84 & 36.60 & 584775.81 \\
\hline Jul-10 & I & 6457 & 157 & 2.84 & 55.26 & 605245.32 \\
\hline \multirow[t]{2}{*}{ Aug-10 } & I & 6457 & 230 & 2.84 & 80.95 & 449262.43 \\
\hline & II & 6457 & 92 & 2.84 & 32.38 & 227280.49 \\
\hline Sep-10 & I & 3350 & 68 & 1.47 & 46.13 & 17313.35 \\
\hline \multirow{2}{*}{ Oct-10 } & I & 6457 & 82 & 2.84 & 28.86 & 549065.85 \\
\hline & II & 6307 & 80 & 2.77 & 28.82 & 550997.80 \\
\hline \multirow[t]{2}{*}{ Jan-11 } & I & 6307 & 76 & 2.77 & 27.38 & 112190.28 \\
\hline & II & 6457 & 72 & 2.84 & 25.34 & 157732.15 \\
\hline \multirow[t]{2}{*}{ Feb-11 } & I & 4645 & 19 & 2.04 & 9.29 & 30566.37 \\
\hline & II & 4455 & 22 & 1.96 & 11.22 & 32362.18 \\
\hline Jun-11 & I & 5445 & 131 & 2.39 & 54.67 & 280024.09 \\
\hline \multirow[t]{2}{*}{ Jul-11 } & I & 6457 & 103 & 2.84 & 36.25 & 174523.67 \\
\hline & II & 6457 & 131 & 2.84 & 46.10 & 305571.58 \\
\hline \multirow[t]{2}{*}{ Aug-11 } & I & 5445 & 90 & 2.39 & 37.56 & 161785.92 \\
\hline & II & 6457 & 105 & 2.84 & 36.95 & 198366.13 \\
\hline \multirow[t]{2}{*}{ Sep-11 } & I & 5445 & 43 & 2.39 & 17.94 & 73715.81 \\
\hline & II & 6457 & 105 & 2.84 & 36.95 & 118591.39 \\
\hline \multirow[t]{2}{*}{ Oct-11 } & I & 6457 & 132 & 2.84 & 46.46 & 206450.75 \\
\hline & II & 5445 & 105 & 2.39 & 43.82 & 108182.5 \\
\hline \multirow[t]{2}{*}{ Jan-12 } & I & 6117 & 52 & 2.69 & 19.32 & 44290.71 \\
\hline & II & 4300 & 27 & 1.89 & 14.27 & 72030.13 \\
\hline \multirow[t]{2}{*}{ Feb-12 } & I & 4790 & 40 & 2.10 & 18.97 & 68260.35 \\
\hline & II & 5162 & 107 & 2.27 & 47.10 & 185938.86 \\
\hline \multirow[t]{2}{*}{ Mar-12 } & I & 6457 & 113 & 2.84 & 39.77 & 114005.86 \\
\hline & II & 5467 & 61 & 2.40 & 25.35 & 91694.42 \\
\hline
\end{tabular}

identify. For spider monkeys, a folivorous diet might increase the amount and diversity of toxins and secondary metabolites consumed, which could have both direct and indirect influences on their nutrition and health. It may be significant, then, that in most long-term studies spider monkeys are reported to feed on clay from mineral licks (Izawa 1993, Link et al. 2011a,b), which is suggested to be one means by which they cope with the effects of secondary metabolites. Spider monkeys at San Juan and elsewhere are also reported to feed on decayed wood from dead standing trees (Suarez 2006, Di Fiore et al. 2008, Chaves et al. 2012), which may allow them access to additional minerals not otherwise available in their diet (Krishnamani \& Mahaney 2000, Ferrari et al. 2008).

In a similar pattern to that reported in most studies on Ateles, figs were an extremely important item in the diet of brown spider monkeys. Ficus constituted the single most important genus of plant consumed by brown spider monkeys, averaging $24.1 \%$ of their diet across months and reaching up to $68.1 \%$ of the monthly time devoted to feeding (Fig. 4). At La Chonta in lowland Bolivia, spider monkeys also relied heavily on figs in their diet, leading Felton et al. (2008) to propose that figs were staple food items, as they were available almost all year, and monkeys fed on them even during periods of fruit abundance. Based on the results of our study, figs at San Juan can also be considered staple food items, as they were present in the diet of brown spider monkeys throughout the study. At San Juan, spider monkeys fed on both ripe and unripe fruits

forests of Las Quinchas (55 vs. $123 \mathrm{spp}$.). The lower diversity in the diet of spider monkeys at San Juan may be due to the fact that they inhabit a seasonally flooded forest with lower overall species richness (72.5 species $\mathrm{ha}^{-1}, \mathrm{n}=2$ ) than terra firme forests (160.5 species ha ${ }^{-1}, \mathrm{n}=4$ ) at las Quinchas (Stevenson et al. 2011). Overall, the diet of spider monkeys at San Juan was less diverse than that found in most other long-term studies of wild spider monkeys (Table 3).

The dietary diversity of brown spider monkeys at San Juan might have been underestimated due to the fact that a large proportion of feeding bouts took place on lianas and epiphytes that we were unable to (also see Felton et al. 2008), and they also heavily relied on young leaves from Ficus dendrocida and F. insipida year-round.

Although at other sites spider monkeys have been reported to include a large proportion of leaves during periods of fruit scarcity (Symington 1987, Chapman \& Chapman 1990, Wallace 2005) and when living in disturbed and fragmented habitats (González-Zamora et al. 2009, Chaves et al. 2012), there is scant information on the potential effects of extensive leaf consumption on their reproduction and health. This is particularly relevant given the fact that at San Juan, spider monkeys do not invest large portions of their time in resting and processing the large quan- 


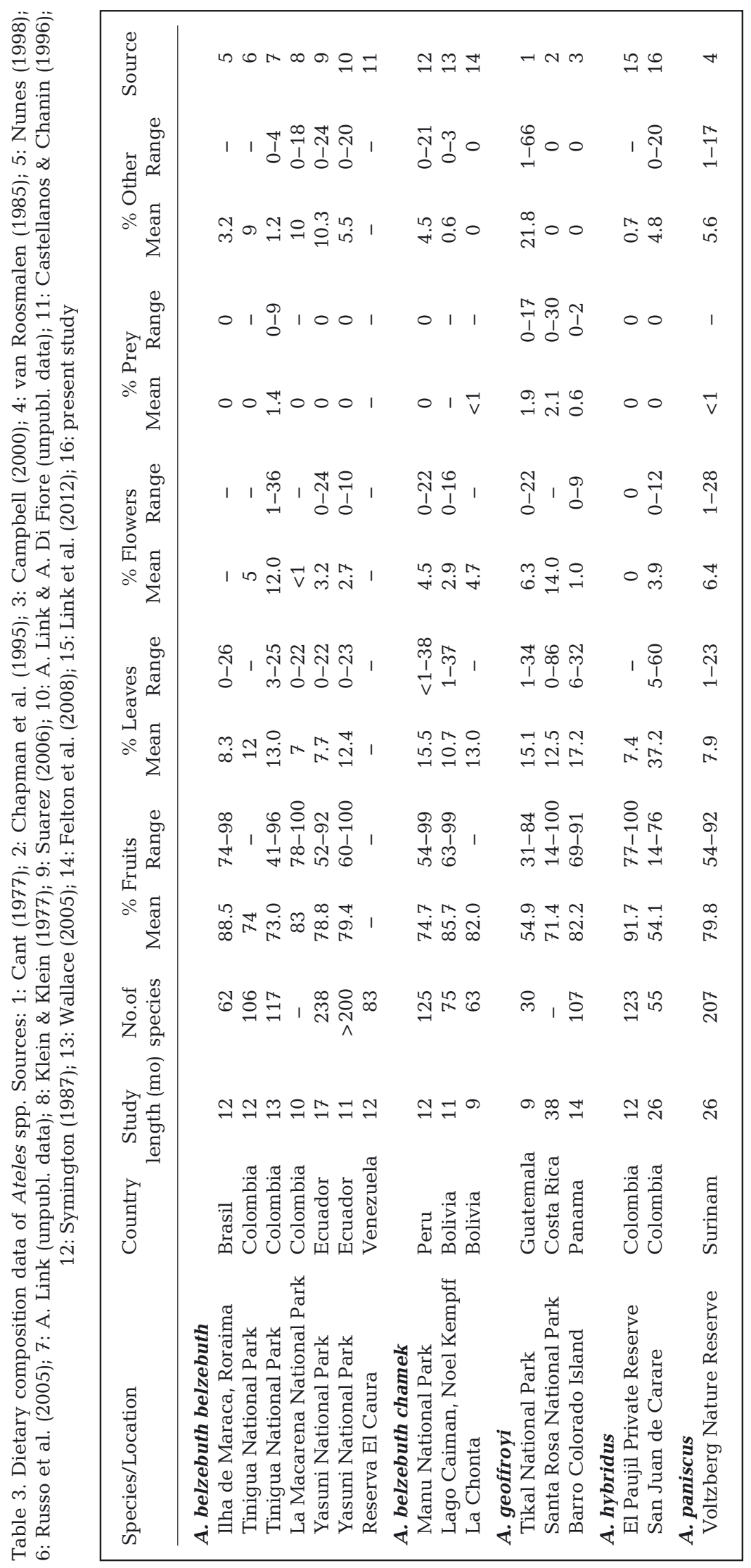

tity of leaves in their diet. The digestive system of spider monkeys seems best suited for feeding on fleshy ripe fruits - they have very short gut passage times (ca. 4.5 h; Link \& Di Fiore 2006) and they also generally feed on leaves prior to long resting bouts, where their metabolism is lower and there may be more time for leaves to be efficiently processed in their digestive system (Chapman 1995). Thus, spider monkeys may be physiologically restricted as to the amount of leaves they can include in their diet. In fact, Wallace (2005) found that during periods when spider monkeys relied most heavily on leaves, their body condition seemed to deteriorate. Given that habitat fragmentation is pervasive across the areas within the historical distribution of spider monkeys (see Link et al. 2013), there is an urgent need to better understand the effect of fragmentation and habitat degradation-not only on spider monkeys' feeding ecology, but also on their longterm population dynamics. Under the suboptimal conditions of a low-quality diet in fragmented landscapes, spider monkeys may develop more slowly or experience longer inter-birth intervals. They may also face increased stress levels, higher parasitic loads (Rimbach et al. 2015) and even lower survival in fragmented landscapes, which, coupled with hunting and other anthropogenic factors, may increase the risk of local extinctions.

Acknowledgements. We thank all students and collaborators of Fundacion Proyecto Primates who contributed to the long-term study and conservation of brown spider monkeys at San Juan de Carare. We are grateful to the Lalinde and De Greiff families for allowing us to conduct research at San Juan de Carare since 2007. We also thank the editor and 3 anonymous reviewers who significantly contributed to the final version of the manuscript. This project was funded by WCS-Research Fellowship Programme, Rufford Small Grants Foundation, Primate Conservation Inc., Primate Action Fund, National Geographic Society-CRE and the National Science Foundation BCS1025675. 


\section{LITERATURE CITED}

Achard F, Eva HD, Stibig HJ, Mayaux P, Gallego J, Richards T, Malingreau JP (2002) Determination of deforestation rates of the world's humid tropical forests. Science 297: 999-1002

*Aide TM, Clark ML, Grau HR, López Carr D and others (2013) Deforestation and reforestation of Latin America and the Caribbean (2001-2010). Biotropica 45:262-271

Altmann J (1974) Observational study of behavior: sampling methods. Behaviour 49:227-267

Arroyo-Rodríguez V, Mandujano S (2006) Forest fragmentation modifies habitat quality for Alouatta palliata. Int $\mathrm{J}$ Primatol 27:1079-1096

Arroyo-Rodríguez V, González-Perez IM, Garmendia A, Solà M, Estrada A (2013) The relative impact of forest patch and landscape attributes on black howler monkey populations in the fragmented Lacandona rainforest, Mexico. Landsc Ecol 28:1717-1727

Asensio N, Korstjens AH, Schaffner CM, Aureli F (2008) Intragroup aggression, fission-fusion dynamics and feeding competition in spider monkeys. Behaviour 145: 983-1001

Asensio N, Korstjens AH, Aureli F (2009) Fissioning minimizes ranging costs in spider monkeys: a multiple-level approach. Behav Ecol Sociobiol 63:649-659

Aureli F, Schaffner CM, Boesch C, Bearder SK and others (2008) Fission fusion dynamics. Curr Anthropol 49: 627-654

Campbell CJ (2000) The reproductive biology of blackhanded spider monkeys (Ateles geoffroyi): integrating behavior and endocrinology. PhD dissertation, University of California, Berkeley, CA

Cant JGH (1977) Ecology, locomotion, and social organization of spider monkeys (Ateles geoffroyi). $\mathrm{PhD}$ dissertation, University of California, Davis, CA

Castellanos HG, Chanin P (1996) Seasonal differences in food choice and patch preference of long-haired spider monkeys (Ateles belzebuth). In: Norconk MA, Rosenberger AL, Garber PA (eds) Adaptive radiations of Neotropical primates. Plenum Press, New York, NY, p 451-466

* Chapman CA (1987) Flexibility in diets of three species of Costa Rican primates. Folia Primatol (Basel) 49:90-105

* Chapman CA (1990) Association patterns of spider monkeys: the influence of ecology and sex on social organization. Behav Ecol Sociobiol 26:409-414

* Chapman CA (1995) Primate seed dispersal: coevolution and conservation implications. Evol Anthropol 4:74-82

Chapman CA, Chapman LJ (1990) Density and growth rate of some tropical dry forest trees: comparisons between successional forest types. Bull Torrey Bot Club 117: 226-231

Chapman CA, Chapman LJ, Wrangham RW (1995) Ecological constraints on group size: an analysis of spider monkey and chimpanzee subgroups. Behav Ecol Sociobiol 36:59-70

Chapman CA, Ghai R, Jacob A, Koojo SM and others (2013) Going, going, gone: a 15-year history of the decline of primates in forest fragments near Kibale National Park, Uganda. In: Marsh LK, Chapman CA (eds) Primates in fragments: complexity and resilience. Springer, New York, NY, p 89-100

Chaves OM, Stoner KE, Arroyo-Rodríguez V (2011) Seasonal differences in activity patterns of Geoffroyi's spider monkeys (Ateles geoffroyi) living in continuous and frag- mented forests in southern Mexico. Int J Primatol 32: 960-973

* Chaves OM, Stoner KE, Arroyo-Rodríguez V (2012) Differences in diet between spider monkey groups living in forest fragments and continuous forest in Mexico. Biotropica 44:105-113

Di Fiore A, Link A, Dew JL (2008) Diets of wild spider monkeys. In: Campbell CJ (ed) Spider monkeys: behavior, ecology and evolution of the genus Ateles. Cambridge University Press, Cambridge, p 81-137

Fahrig L (2003) Effects of habitat fragmentation on biodiversity. Annu Rev Ecol Evol Syst 34:487-515

Felton AAM, Felton AM, Wood JT, Lindenmayer DB (2008) Diet and feeding ecology of Ateles chamek in a Bolivian semihumid forest: the importance of Ficus as a staple food resource. Int J Primatol 29:379-403

FFerrari SF, Veiga LM, Urbani B (2008) Geophagy in New World monkeys (Platyrrhini): ecological and geographic patterns. Folia Primatol (Basel) 79:402-415

Franzen M (2006) Evaluating the sustainability of hunting: a comparison of harvest profiles across three Huaorani communities. Environ Conserv 33:36-45

*Ganzhorn SM, Perez-Sweeney B, Thomas WW, Gaiotto FA, Lewis JD (2015) Effects of fragmentation on density and population genetics of a threatened tree species in a biodiversity hotspot. Endang Species Res 26:189-199

*González-Zamora A, Arroyo-Rodríguez V, Chaves OM, Sánchez-López S, Stoner KE, Riba-Hernández P (2009) Diet of spider monkeys (Ateles geoffroyi) in Mesoamerica: current knowledge and future directions. Am J Primatol 71:8-20

Hill JL, Curran PJ (2003) Area, shape and isolation of tropical forest fragments: effects on tree species diversity and implications for conservation. J Biogeogr 30:1391-1403

* Holzmann I, Agostini I, Areta JI, Ferreyra H, Beldomenico P, Di Bitetti MS (2010) Impact of yellow fever outbreaks on two howler monkey species (Alouatta guariba clamitans and A. caraya) in Misiones, Argentina. Am J Primatol 72: $475-480$

IUCN (2016) The IUCN Red List of Threatened Species. Version 2016-3. www.iucnredlist.org (accessed 7 December 2016)

Izawa K (1993) Soil-eating by Alouatta and Ateles. Int J Primatol 14:229-242

Klein LL, Klein DB (1977) Feeding behaviour of the Colombian spider monkey. In: Clutton-Brock TH (ed) Primate ecology: studies of feeding and ranging behavior in lemurs, monkeys, and apes. Academic Press, London, p 153-181

Krebs CJ (1989) Ecological methodology. Harper \& Row, New York, NY

Krishnamani R, Mahaney WC (2000) Geophagy among primates: adaptive significance and ecological consequences. Anim Behav 59:899-915

KLehmann J, Boesch C (2004) To fission or to fusion: effects of community size on wild chimpanzee (Pan troglodytes verus) social organisation. Behav Ecol Sociobiol 56:207-216

Link A (2003) Insect-eating by spider monkeys. Neotrop Primates 11:104-107

KLink A, Di Fiore A (2006) Seed dispersal by spider monkeys and its importance in the maintenance of neotropical rain-forest diversity. J Trop Ecol 22:235-246

Link A, de Luna AG, Alfonso F, Giraldo-Beltran P, Ramirez F (2010) Initial effects of fragmentation on the density of three neotropical primate species in two lowland forests 
of Colombia. Endang Species Res 13:41-50

Link A, Galvis N, Fleming E, Di Fiore A (2011a) Patterns of mineral lick visitation by spider monkeys and howler monkeys in Amazonia: Are licks perceived as risky areas? Am J Primatol 73:386-396

Link A, de Luna AG, Arango R, Diaz MC (2011b) Geophagy in brown spider monkeys (Ateles hybridus) in a lowland tropical rainforest in Colombia. Folia Primatol (Basel) 82: 25-32

Link A, Galvis N, Marquez M, Guerrero J, Solano C, Stevenson PR (2012) Diet of the Critically Endangered brown spider monkey (Ateles hybridus) in an inter-Andean lowland rainforest in Colombia. Am J Primatol 74:1097-1105

Link A, de Luna AG, Burbano-Girón J (2013) Estado de conservación en Colombia de uno de los primates más amenazados con la extinción: el mono araña café (Ateles hybridus). In: Defler TR, Stevenson PR, Bueno ML, Guzmán-Caro DC (eds) Primates Colombianos en peligro de extinción. Asociación Primatológica Colombiana, Bogota, p 88-119

Marsh LK, Chapman CA, Arroyo-Rodríguez V, Cobden AK and others (2013) Primates in fragments 10 years later: once and future goals. In: Marsh LK, Chapman CA (eds) Primates in fragments: complexity and resilience. Springer, New York, NY, p 503-523

Mbora DNM, McPeek MA (2015) How monkeys see a forest: genetic variation and population genetic structure of two forest primates. Conserv Genet 16:559-569

Michalski F, Peres CA (2005) Anthropogenic determinants of primate and carnivore local extinctions in a fragmented forest landscape of southern Amazonia. Biol Conserv 124:383-396

Mittermeier RA, Wallis J, Rylands AB, Ganzhorn JU and others (2009) Primates in peril: the world's 25 most endangered primates 2008-2010. Primate Conserv 24: $1-57$

Nunes A (1998) Diet and feeding ecology of Ateles belzebuth belzebuth at Maracá Ecological Station, Roraima, Brazil. Folia Primatol (Basel) 69:61-76

Rimbach R, Bisanzio D, Galvis N, Link A, Di Fiore A, Gillespie TR (2015) Brown spider monkeys (Ateles hybridus): a model for differentiating the role of social networks and physical contact on parasite transmission dynamics. Philos Trans R Soc Lond B Biol Sci 370:20140110

Rosenberger AL, Strier KB (1989) Adaptive radiation of the ateline primates. J Hum Evol 18:717-750

Editorial responsibility: Nils Bunnefeld, Stirling, UK
Russo SE, Campbell CJ, Dew JL, Stevenson PR, Suarez SA (2005) A multi-forest comparison of dietary preferences and seed dispersal by Ateles spp. Int J Primatol 26: 1017-1037

Shimooka Y (2003) Seasonal variation in association patterns of wild spider monkeys (Ateles belzebuth belzebuth) at La Macarena, Colombia. Primates 44:83-90

* Steenbeek R, Assink P, Wich SA (1999) Tenure related changes in wild Thomas's langurs II: Loud calls. Behaviour 136:627-650

Stevenson PR (2002) Frugivory and seed dispersal by woolly monkeys at Tinigua National Park, Colombia. $\mathrm{PhD}$ dissertation, State University of New York, Stony Brook, NY

* Stevenson PR, Quiñones MJ, Ahumada JA (2000) Influence of fruit availability on ecological overlap among four neotropical primates at Tinigua National Park, Colombia. Biotropica 32:533-544

Stevenson PR, Suescún M, Aldana AM, Cano A and others (2011) Diversidad arbórea en bosques de tierras bajas en Colombia: efectos del ambiente, las perturbaciones y la geografía. Hipótesis 12:29-35

Suarez SA (2006) Diet and travel costs for spider monkeys in a nonseasonal, hyperdiverse environment. Int J Primatol 27:411-436

Symington MM (1987) Ecological and social correlates of party size in the black spider monkey, Ateles paniscus chamek. PhD dissertation, Princeton University, Princeton, NJ

Symington MM (1990) Fission-fusion social organization in Ateles and Pan. Int J Primatol 11:47-61

*Templeton AR, Shaw K, Routman E, Davis SK (1990) The genetic consequences of habitat fragmentation. Ann Mo Bot Gard 77:13-27

* van Roosmalen MGM (1985) Habitat preferences, diet, feeding strategy and social organization of the black spider monkey (Ateles paniscus paniscus Linnaeus 1758), in Suriname: a socioecological field study. Acta Amazon 15: $1-238$

Villanueva B (2008) Caracterizacion y descripcion de dos relictos de bosque humedo tropical en la hacienda San Juan del Carare, municipio de Cimitarra, Santander. BSc thesis, Universidad del Tolima, Ibague

Wallace RB (2005) Seasonal variations in diet and foraging behavior of Ateles chamek in a southern Amazonian tropical forest. Int J Primatol 26:1053-1075

Submitted: March 28, 2016; Accepted: November 8, 2016 Proofs received from author(s): January 4, 2017 